\title{
WestVirginiaUniversity
}

THE RESEARCH REPOSITORY @ WVU

West Virginia Agricultural and Forestry Experiment

Davis College of Agriculture, Natural Resources

Station Bulletins

And Design

$1-1-1943$

\section{Tri-state cherry-spray investigations}

\author{
A. B. Groves \\ H. J. Miller \\ Carlton F. Taylor
}

Follow this and additional works at: https://researchrepository.wvu.edu/ wv_agricultural_and_forestry_experiment_station_bulletins

\section{Digital Commons Citation}

Groves, A. B.; Miller, H. J.; and Taylor, Carlton F., "Tri-state cherry-spray investigations" (1943). West Virginia Agricultural and Forestry Experiment Station Bulletins. 310.

https://researchrepository.wvu.edu/wv_agricultural_and_forestry_experiment_station_bulletins/311 @ WVU. It has been accepted for inclusion in West Virginia Agricultural and Forestry Experiment Station Bulletins by an authorized administrator of The Research Repository@WVU. For more information, please contact ian.harmon@mail.wvu.edu. 
West Virginia University Libraries 



\section{Tri-State Cherry-Spray Investigations}

By A. B. Groves, H. J. Miller, and C. F. TaYlor

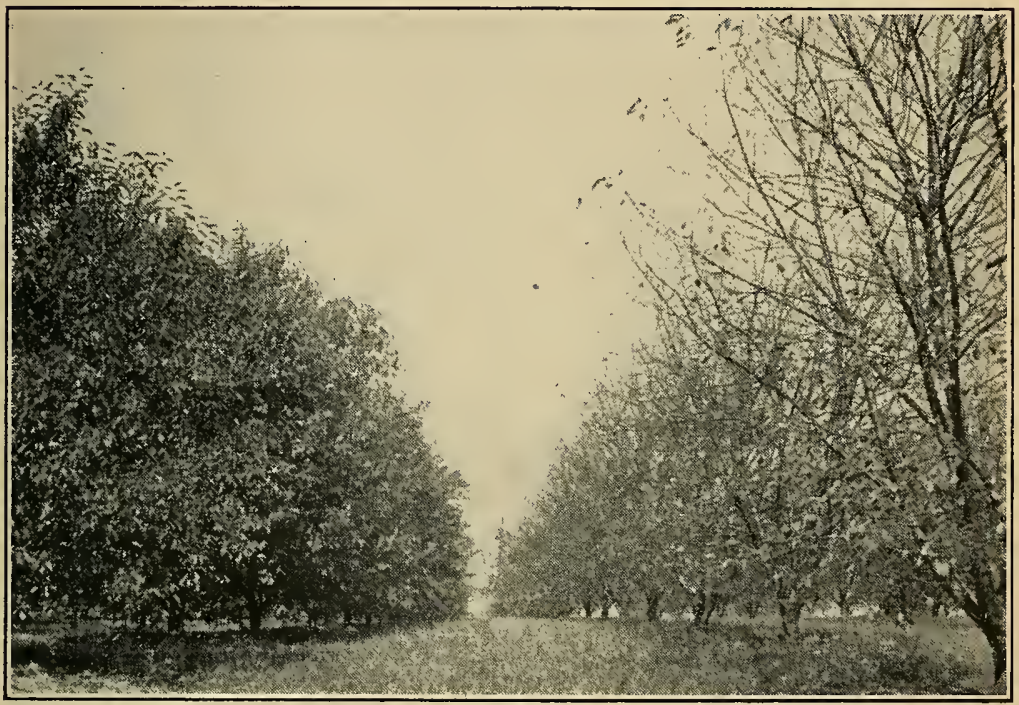

CORRECT SPRAYS CONTROL DEFOLIATION

AGRICULTURAL EXPERIMENT STATION

COLLEGE OF AGRICULTURE, FORESTRY, AND HOME ECONOMICS

WEST VIRGINIA UNIVERSITY

C. R. ORTON, DIRECTOR

MORGANTOWN

IN COOPERATION WITH THE AGRICULTURAL EXPERIMENT STATIONS

OF PENNSYLVANIA AND VIRGINIA 


\section{PREFACE}

This publication presents a report of three years of cooperative cherry spray investigations, the purpose of which was to develop a more satisfactory spray schedule for the entire region involved. The problem approached was a regional one and the cooperative participation of those states within which the region lay seemed logical and proper. The decision upon a course of action was fostered and its actual initiation expedited by the experience and benefit gained from the annual Cumberland-Shenandoah Conferences. Experiment station and federal workers interested in the problems of fruit growing have met together annually for a number of years to present and exchange experimental findings for the purpose of unifying recommendations for what is essentially one region, although included within several states.

The progress made as a result of the cooperative effort here reported has been most gratifying to those participating. It is felt that greater and more rapid progress has been made than if there had been no coordination of effort. Certainly the results obtained and the conclusions drawn can properly be regarded as applying better to the whole region, and to reflect variation of environmental conditions from state to state more accurately, than if independent and uncorrelated investigations had been conducted.

There was no seniority of administration of the project as there is no seniority of authorship of this report. Each participant was responsible for the conduct of the trials within his state.

This publication has not been planned as a concluding report on these investigations, although in view of present conditions, such may necessarily be the case.

Each of the three states are offering this publication in identical context, although under numerical bulletin designation numbers in accordance with the order number reached at each station.

The Authors

$* \quad * \quad * \quad * \quad *$

This bulletin is also printed as bulletin 447 of the Pennsylvania Agricultural Station and as bulletin 354 of the Virginia Agricultural Station, with no change in text or authorship. 


\section{TRI-STATE CHERRY-SPRAY INVESTIGATIONS}

A. B. Groves, Assistant Plant Pathologist, Virginia Agricultural Experiment Station;

H. J. Miller, Assistant Plant Pathologist, Pennsylvania Agricultural Experiment Station; and C. F. TaYlor, Assistant Plant Pathologist, West Virginia Agricultural Experiment Station

The sour cherry (Prunus Cerasus L.) is grown extensively throughout the Eastern United States, and is commercially important in several sections of this general region. The Montmorency is the most widely planted variety in Southeastern Pennsylvania, the panhandle of West Virginia and adjacent Maryland, and the Northern part of Virginia, an area commonly known as the Cumberland-Shenandoah Valley.

Leaf spot (Coccomyces hiemalis Higgins) is the most important disease of the Montmorency, as well as other varieties of sour and sweet cherries in this region. This is also true in most other sections of the country where cherries are grown commercially. Spray practices commonly employed on the sour cherry were developed primarily for the control of this disease.

Leaf spot is the principal cause of premature cherry leaf drop, and in orchards unprotected by fungicidal sprays, most of the leaves are lost prematurely as a result of leaf spot. The infected leaves drop to the ground during the late summer and fall and the causal fungus overwinters on them. The fungus enters the saprophytic phase in these dead leaves and continues growth and ramification within the leaf for a period of several months. Toward the end of this period the perfect or ascogenous form of the fungus develops, terminating in the production of ascospores which are discharged from shallow apothecia on the lower leaf surface. Ascospores are discharged in the spring during periods of rainfall adequate to moisten the old leaves. Spores coming to rest on a leaf may initiate an infection, commonly termed a "primary" infection, as distinguished from those produced afterward by conidia and termed "secondary" infections. A few conidia are produced in the apothecia on the old leaves following the discharge of ascospores, but their relative importance in producing primary infections remains in some doubt. The amount of primary infection produced generally seems to be small, yet it appears to be the connecting link between the overwintering phase and the severe epiphytotic or conidially-spread phase which usually develops by mid-summer.

The appearance of small reddish or purple spots which develop within about a week following infection are the earliest visilie symptoms of leaf spot. 
These spots become brown as they enlarge with age, although they never become large. The spots, or lesions, are generally more numerous near the tip and the margins of the leaf, although they occur over the entire surface. Lesions may become so numerous that they coalesce and thus kill large areas of the leaf, although yellowing and abscission has been the most frequent response to severe infection as observed in this region. The shot-hole type of response to severe infection has been observed only infrquently during the course of these experiments. Petiole and pedicel infections have been observed only rarely. Leaves develop a chlorotic or yellow cast as the severity of infection develops, and drop shortly after the yellowing symptoms become apparent. These yellow leaves are readily knocked off by rains, and it seems well to note here that, if yellow foliage may be considered a criterion, the condition of the foliage in an orchard may well be misjudged when observed shortly following a shower.

The imperfect or conidial stage (Cylindrosporium hiemalis Higgins) develops with the establishment of primary infections. Conidia are produced in masses over the lesions on the lower surface of the leaf, and are readily washed away by rain, numerous infections resulting from the spores thus scattered when conditions of temperature and humidity are favorable. From one to two weeks are required for a new infection to develop to the sporulating stage. Where weather conditions are favorable successive waves or cycles of infection can cause a very rapid increase in the amount of disease, frequently reaching epiphytotic proportions by midsummer. Defoliation begins as the number of infections per leaf increases to a critical point and continues, generally, at an accelerating rate, until defoliation is complete.

The requirements imposed upon a fungicide and the schedule of its use in the control of cherry leaf spot may be considered as twofold. . The first requirement is to afford protection during the early part of the season when most infection is of the primary type, and second, the ability to prevent infection from the much more numerous and generally more viable conidia. Lime-sulfur, for example, has generally met the first requirement satisfactorily, but has not always filled the second. The requirements as expressed here are essentially reversed from the situation as it exists in the case of apple scab where primary infection is more difficult to control than the secondary. An understanding of these considerations seems essential to the development of a satisfactory spray program.

Liquid lime-sulfur had been the standard fungicide used on cherries for many years in the Cumberland-Shenandoah region, as well as in many other sections. The prevailing rate of usage was probably $1-40$, although it was used as strong as 1-33 and as weak as 1-500. The material had not been wholly satisfactory, although little concerted effort to improve the situation in this region had been made prior to the extensive and early defoliation of orchards which occurred in the 1937 leaf' spot epiphytotic. This demon- 
stration of the lack of adequate fungicidal effectiveness of lime-sulfur, coupled with the development of late season spray injury and frequent scalding of fruit from applications made shortly before harvest, served to emphasize the necessity of investigations directed toward a clarification and improvement of the situation. An earlier publication (14) reported the results obtained the first year of this cooperative study of cherry leaf spot. The report which follows outlines the results obtained during the full three years of these investigations.

The principal objectives of these investigations were the selection of a more effective fungicide and the formulation of a more satisfactory spray schedule than those in current use. The control of leaf infection and consequent defoliation served as a measure of fungicidal effectiveness, although not the only basis of preference because of certain possible secondary effects. The planned approach was logically through field trial and thorough analysis of the results observed. Observations upon the effect of various materials and schedules as reflected in spray injury, unsound fruit, size of fruit, and soluble solids contents were also planned. Data on some of these developments were not planned nor taken every season, but to a certain extent their inclusion resulted from observations made during the course of the experiment.

The prime requisite for a uniform approach to the problem by the cooperating stations seemed to be an agreement upon uniform methods of procedure and of recording data. Such a memorandum was drawn up and agreed upon by the participating members and is presented here. It should be noted that the experiment was not planned as a three-year trial to be rigidly adhered to throughout the period, but rather the necessity of a certain flexibility of plan from year to year was recognized as a prerequisite to profiting fully from each season's experience. For this reason a variation in rates of usage of some materials will be noted as well as the dropping of some and the inclusion of others, along with schedule alterations and similar changes. The memorandum of uniform procedure as agreed upon and observed by the three states is given. Notes upon any deviations, together with proper explanation are included in the discussion of relevant topics.

\section{Memorandum of Uniform Procedure}

1. Variety used: Montmorency, the only commercially important variety in this region.

2. Plots: Consisted of seven randomized single tree replicates, with data taken from six. The extra tree allowed for the possible loss of one replicate due to unforeseen circumstances.

3. Fungicides in uniform lot: All proprietary fungicides were obtained from a single plant batch lot where possible to eliminate this possible source of variation. 
4. Lead arsenate: General Chemical Company regular lead arsenate 2 lbs. per 100 gallons was used wherever lead arsenate was required.

5. Lime: Gold Bond Spray lime from the Oranda, Virginia, plant of the National Gypsum Company was used where lime was indicated. This is a high calcium hydrate prepared specially for spray use. The rate of usage of lime varied with certain fungicides, and the rates are therefore indicated on each season's spray schedule.

6. Schedules: Two general schedules were used, a regular four-spray schedule (petal-fall, shuck, first cover or three-week, and post-harvest) and a like schedule modified with the insertion of a pre-harvest spray. The first application was made immediately after the major portion of the petals had fallen; the shuck spray as soon as three-fourths of the shucks (calyces) had split and fallen (usually about 10 days after petal fall); the first cover spray followed approximately three weeks after the shuck spray, or at about the time the fruit first showed color; the pre-harvest immediately preceded picking of the fruit; the post-harvest was applied as soon as practicable after the completion of picking.

7. Records taken:

Leaf data: Defoliation records were taken in the following manner: Just prior to the first cover spray six well distributed branches per tree were tagged at a point back of 00 leaves and either the terminal bud removed to prevent further growth where necessary, or a second tag placed so that the two bracketed the desired 50 leaves. The small, weak or otherwise unsuitable leaves were removed to avoid later confusion or error. Each tagged branch constituted a station and was numbered for identification. Counts of leaves remaining were made during the first week of August, September, and October or at other appropriate intervals in accordance with seasonal developments. The number of infected leaves per station was usually recorded at the same time, although sometimes at other intervals as determined by the progress of leaf infection.

Fruit data: The effect of the various materials upon fruit size was recorded through the gathering of random samples from each tree at picking time and counting the number of fruits per pound. The soluble-solids content of the fruit was determined by means of refractometer readings of the juice from each tree sample. Brown rot infection counts, to be taken at picking time, were planned if disease conditions warranted.

8. No deviations were made from the agreed procedure without first consulting or informing the other cooperating members of the group.

\section{MATERIALS}

The development of a more satisfactory spray program for cherries was approached from two angles. The first involved the testing of numerous 
fungicidal materials in an attempt to locate a more satisfactory fungicide. The second approach was through the employment of split schedules and schedule modifications. This was done in an attempt to better fit the different types of materials to the place where they were found best suited and thus to construct the best possible complete schedule. Certain amendments, particularly so-called spreaders and stickers, were included for limited trial in order to determine their possibilities in improving both the effectiveness and safety of the materials with which they were used.

Three general types of materials were utilized in the experimental trials; sulfur compounds, principally lime-sulfur; copper base materials including Bordeaux mixture and proprietary copper products; synthetic organic materials of various types.

Selection of materials the first year was largely a matter of choosing from numerous materials commercially available which seemed to offer promise, judged both on the basis of experience elsewhere and of limited observations in the Cumberland-Shenandoah region.

Bordeaux mixture was prepared by the "instant" method of Schneiderhan (11) which is a universal practice in this region. Tank-mix copper phosphate was prepared according to the method developed by R. H. Daines of the New Jersey Agricultural Experiment Station and in accordance with instructions provided in correspondence. Tank mix ferric dimethyl dithiocarbamate was prepared according to instructions provided by M. C. Goldsworthy of the U. S. Department of Agriculture. The proprietary fungicides were generally added directly to the partially filled spray tank with the agitator running.

The proprietary coppers were generally employed on a copper-equivalent basis. The existence of valid objections of the treatment of all materials on such a basis without regard to other factors is recognized, but such a procedure was felt to be justified by the provision of a uniform basis for comparison. Three-fourths pound of metallic copper per 100 gallons of spray was the rate of usage generally employed during 1940 and 1941; onehalf pound was used in 1942.

All proprietary products were provided gratuitously by the several manufacturing companies. A request to the various manufacturing concerns asking that materials be provided from a single plant batch to all three cooperators where possible. was accepted by all companies. The uniformity of product thus obtained reduced by one the possible variables which might operate to produce differing results at the three stations. Uniform brands of lead arsenate and spray lime were purchased for the same reason, although here no effort was made to obtain lots from a single plant batch. The liquid lime-sulfur used was a standard $32^{\circ}$ Baumé commercial product purchased by each station and considered to be uniform only so far as a Baumé hydrometer test can be considered a measure of the character of the product. 
The proprietary copper fungicides employed in these experiments were for the greater part not experimental products in that most of them have undergone rather widespread testing on many crops and have found a place in the program of some. They are all reasonably well standardized, and are offered for sale and recommended for use on various crops. Most of these products have been employed on sour cherries to some extent in other regions.

The organic materials used were in all instances experimental products, or of only limited commercial use. Some of these had already received preliminary field trial as fungicides, while others were virtually untried.

Proprietary spray adjuvants included three spreader-sticker compounds, Nufilm, Orthex and S. E. C. oil. A complete list of the proprietary and experimental products used, together with their composition and source follows: Apple Coposil . . . . . . . California Spray Chemical Corp. Copper-ammonium-silicate complex plus zinc salt buffer

Basicop

Basic copper sulfate

Bordow

Dry Bordeaux prepared with magnesium hydroxide

Dow Chemical Company Copper-A Compound

Copper oxychloride

Copper Hydro

Hydroxided basic copper sulfate

Cupro-K

E. I. duPont de Nemours \& Company

Sherwin Williams Company

Copper oxychloride

Tennessee 26 Fungicide

Low copper basic copper sulfate

Tennessee 34 Fungicide

High copper basic copper sulfate

Z-O

Copper-alumino-silico phosphate complex

Chipman Chemical Company

Rohm \& Haas Company 
Spergon (wettable)

Tetrachlorobenzoquinone

Mike Sulfur

Elemental sulfur preparation

Nufilm

\section{Rosin residue emulsion}

Orthex

Mineral oil emulsion with additives

S. E. C. Oil

Self emulsifying (miscible) cotton seed oil
Naugatuck Chemical Division

U. S. Rubber Company

Dow Chemical Company

Miller Chemical Company

California Spray Chemical Corp.

Rohm \& Haas Company

\section{METHODS}

The spray schedules employed were uniform for all three stations, as already noted. The dates for the several applications were not uniform because of differences in latitude and elevation which caused variation in the stage of tree development between stations on the same calendar date. Applications were made instead at periods of like tree development. Actual spray applications were made in all instances with a truck mounted power sprayer. Multiple-nozzle brooms were used in Virginia with one operator on the ground and a second operator on a tower above the sprayer. A single-nozzle gun was used in Pennsylvania, being operated from the ground only. Pressure in the neighborhood of 400 pounds per square inch was used in both of these states. The technique of application varied in West Virginia; application was made from the ground and tower using multiple-nozzle brooms at 500 pounds pressure in 1940; in 1941 and in the first two applications in 1942, a multiple-nozzle broom was used from the ground at pressures of 450 to 500 pounds pressure. The last three applications in 1942 were made with a single-nozzle gun from the ground only, at a pressure of 600 pounds. Variations in technique of application were necessitated by topographical characteristics of the various test orchards. The orchard utilized in West Virginia in 1941 and 1942 contained numerous rock outcrops which so restricted sprayer movement that tower spraying was made impossible. Attempts were made to complete each application in one day. Plots consisted of single trees, randomized and replicated seven times.

Leaf data were recorded in the same manner utilized earlier (14) with only minor modifications. Six stations and 300 leaves per tree were used instead of the 10 stations and 500 leaves used the first year. Analysis of data obtained in 1941 had shown the smaller number of stations to be adequate. The stations were distributed according to pattern, although care was taken to avoid obviously weak or badly shaded branches. Three stations were located in the upper part of the tree and three were distributed about the 
outer periphery of the tree at approximately shoulder level. The stations were numbered so that they could be identified at each count. One extra tree replicate was included, and from one to three additional stations were tagged per tree at the time of station selection to provide an extra, or extras, to compensate for the possible loss of some stations which almost always occurred during harvest. All counts were made from the same stations once they were finally selected; this selection was made at the time of the first count instead of at the time they were first tagged, however, which was just before the first cover application. The stations were tagged at this time in order to detect any defoliation due to spray injuries which in some seasons develops appreciably at this time. Counts of the leaves remaining were made at monthly intervals following the initial count made the first week of August. The final count was made in early October. Although some plots retained much of their foliage for another month, it was felt that an additional count would reveal little of importance, and might be complicated by such factors as frost.

\section{RESULTS}

Control of Defoliation.-The leaf retention data for 1940, 1941, and 1942 are given in tables 2, 4, 6. It will be noted that in all three years the condition of the foliage on those plots receiving the standard spray schedule of lime-sulfur was among the poorest of all treated plots, far below those receiving copper type fungicides. Bordeaux mixture made the poorest showing of the copper materials on the basis of leaf retention in 1940 (table 2), although not significantly poorer statistically (99:1) than Z-0, Basi-Cop, Tennessee 26 plus Orthex, or a split schedule of 3 lime-sulfur sprays and 1 Bordeaux spray. The other proprietary coppers proved better than Basi-Cop and Z-0 and these were accordingly dropped from further trial. Tank mix copper phosphate appeared better than Bordeaux, although it did not prove significantly so. The tank mix copper phosphate seemed to have no obvious advantage over Bordeaux, and its very persistent residue was considered a disadvantage, so it too was dropped. Phenothiazine performed poorly and was also discontinued. Copper-A Compound, Tennessee 26 plus Nufilm, Tennessee 26, Copper Hydro, and Cupro $\mathrm{K}$ were all significantly better than Bordeaux mixture. Bordeaux mixture was continued however, because of its position as a standard fungicide and for its usefulness as a standard against which to check the proprietary copper fungicides. The Bordeaux mixture formula employed was not the same all three seasons however, the amount of lime used being increased after the first year. A 2-4-100 formula was used the first year, 2-8-100 the second and third seasons.

The performance of Tennessee 26 was not significantly affected by the stickers used with it; hence, experimental trial with these materials was discontinued. 
The 1941 results (table 4) again demonstrated lime-sulfur to be inferior to the copper materials in leaf retention, and also showed a split schedule of 3 lime-sulfur and one Bordeaux application to be inferior to an all-season schedule of either Bordeaux or one of the proprietary coppers. The split schedule of lime-sulphur and Bordeaux was superior to the complete lime-sulfur program, however. Bordeaux mixture, which had been inferior to the proprietary coppers in the control of defoliation in 1940, was not significantly different from them in this respect in 1941. The appearance of the Bordow plots was noticeably the best of all treatments and on the basis of leaf retention, was significantly better than the Cupro-K plots, the lowest ranking copper treatment. Tennessee 34, Tennessee 26, Copper-A Compound, Copper Hydro, and Apple Coposil, were also all significantly better than Cupro-K. The organic fungicides (Japanese Beetle Spray and Fermate) ranked relatively much better than in 1940 and were significantly better than limesulfur. Their performance approximated that of lime-sulfur and Bordeaux in a split schedule (plot 2).

Cupro-K was used with S. E. C. Oil because of claims of improved safety and fungicidal effectiveness for the combination. The 1941 data did not reveal any significant difference in the performance of Cupro-K, whether used alone or with the S.E. C. Oil, and further trials were therefore not planned.

The 1942 results (table 6 ) revealed Bordeaux mixture to be the most effective copper fungicide under the severe leaf spot conditions which prevailed that season. Bordow proved to be the most effective of the proprietary copper materials used in a 4-spray schedule, although equaled by Tennessee 26 in two כ̆-spray schedules, in one of which Japanese Beetle Spray was employed in the pre-harvest application. The proprietary coppers were significantly (99:1) poorer than Bordeaux mixture. Bordow, Tennessee 26, and Copper Hydro proved significantly better than Cupro-K, Coposil, and Copper-A Compound. Lime-sulfur failed completely in the control of leaf spot, the failure becoming apparent by midsummer. Compound 341, an organic fungicide, was slightly superior (significant only at (19:1) to Bordeaux mixture in the control of leaf spot. Fermate performed fairly well, better than the same type of material produced as a tank mix. The Spergon plots held up little better than the unsprayed checks.

Defoliation began earliest and progressed most rapidly in Pennsylvania, followed successively by West Virginia and Virginia. No appreciable amount of foliage remained on the trees in the Pennsylvania plots by October 1, other than on the all-season Bordeaux plot. Defoliation in West Virginia on the same date was less severe, although here only the plot sprayed with Compound 341 was in good condition (8כ percent foliage remaining) and but two other plots, Bordeaux all-season and a split schedule of 2 lime-sulfur and 2 Bordeaux sprays, had as much as one-third of the leaves remaining. The Virginia plots were in much better condition at this time. 
The spreading agents used the previous seasons did not affect the performance of the fungicides with which they were used, either favorably or unfavorably. They were therefore not used in 1942, being regarded as an added cost without compensating benefit.

Judged on the basis of results for three years at three stations, both Bordeaux mixture and certain of the proprietary copper fungicides are satisfactory for use on the sour cherry, where disease control only serves as the basis of evaluation. Other factors enter into the selection of a satisfactory fungicide however, and these considerations are treated under the discussion of Effects on the Fruit. The copper materials were in all instances superior to lime-sulfur in disease control. The organic fungicides proved generally disappointing, although the fungicidal effectiveness of Compound 341 was as surprising as it was gratifying.

Effects on the Fruit.- The effect of spray materials on the fruit was studied as it was reflected in effect upon fruit size and upon the soluble solids content of the fruit. The method of obtaining data on fruit size has already been given and needs no further elaboration. Fruit samples were gathered from a number of points on the tree, and so far as possible all were taken the same day to avoid the possibility of changes due to further development.

Reduction in fruit size on trees sprayed with Bordeaux and other alkaline sprays is a phenomenon widely acknowledged and first reported by Fisher (5) in work on sweet cherries, and by Dutton and Wells (3) on the sour cherry. These observations have been confirmed by a number of investigators in more recent reports.

Bordeaux and tank mix copper phosphate, in the experiments here reported, in 1940 significantly reduced the size of the fruit as compared with the check, as well as below the proprietary coppers. Lime-sulfur, the proprietary coppers and phenothiazine also reduced the size of the fruit below the unsprayed check. Fruit weight differences between phenothiazine, lime-sulfur and the proprietary coppers were not significant in 1940.

Bordeaux significantly reduced the size of the fruit below the check, the proprietary coppers and the organics in 1941. Fruit from the Bordow plots was also smaller in size, but the difference was barely significant. Other differences were minor and not significant.

The 1942 results were more variable than in the previous seasons, a development possibly attributable to crop differences. The 1942 crop was heavy in Pennsylvania, moderate in West Virginia, and very light in Virginia. Bordeaux significantly reduced the size of fruit below the proprietary coppers, the check, lime-sulfur and the organics in Pennsylvania. None of these differences were significant in all three states, although the reduction in size by Bordeaux and lime-sulfur below that of the organics was significant in both Pennsylvania and West Virginia. 
Fruit samples from each plot replicate were crushed and the expressed juice used in making soluble solids determinations, which were made in 1941 and 1942 only. Refractive index readings of the juice were made with an Abbé refractometer in Pennsylvania and Virginia, and the readings converted to percentage of sugar by means of Schönrock's Table (2). The West Virginia readings were made with a Zeiss hand refractometer calibrated to read directly in percentage of sucrose. ${ }^{1}$ The juice analyses are recorded in tables 4 and 6 and are expressed as soluble solids, since the juice as analyzed was a composite water solution of sucrose, invert sugars, fruit acids and other substances present in minor amounts. The refractive indices of these substances are not identical with that of sucrose, and a sucrose table will not give an entirely true expression of the total soluble solids. The converted readings can be considered an accurate expression of the soluble solids content only to the extent that the refractive index of the solution of mixed solids parallels that of sucrose. Approximately 80 percent of the sugar content of the cherry is in the form of invert sugars with a refraction index correction factor of 1.022. The readings would therefore be slightly higher than those recorded if corrected for this variable. No reports of the correlation between the soluble solids and sugar content of the cherry have come to our attention. Allinger et al. (1) in a report on the soluble solids content of melon juice as determined by various analytical methods concluded that although there were slight and consistent variations in accuracy, the results obtained by hand and Abbé refractometers, or by analysis of the dried residue, were closely correlated and that any of the methods may be used to measure soluble solids. Porter et al. (9) in studying the correlation of total soluble solids and total sugars in the watermelon concluded that there is a close correlation of total soluble solids and total sugars. They state that, "It is evident that the trend in refractometric readings follows closely the trend in sugar content as determined chemically for the different varieties investigated, which gives proof of the interdependence of refractometrie readings and sugar content."

The percentage of soluble solids content of fruit from the Bordeaux plots was increased the two years that juice analyses were made. The increase in soluble solids might thus seem to be only an apparent difference. Such an interpretation was suggested by Rasmussen (10) who states, "The high percentage of solids in the fruit sprayed with Bordeaux may be due to the increased transpiration caused by these materials which resulted in the production of smaller fruit." Calculations of the total amount of sugar per 100 fruits, however, revealed an actual increase in weight as well as in concentration of sugar in 1941. To a less extent, the same was true with Bordow. Differences in 1942 were not significant.

\footnotetext{
${ }^{1}$ The assistance of the C. H. Musselman Company, Biglerville, Pennsylvania, and the National Fruit Product Company, Winchester, Virginia, in making certain analyses and in use of equipment is gratefully acknowledged.
} 
The soluble solids content of fruit from the Bordeaux sprayed plots was significantly higher in 1941 than fruit from the check, lime-sulfur, organic, and proprietary copper plots. Lime-sulfur sprayed fruits were somewhat higher in soluble solids than fruit from the check and organic fungicide plots, but the differences were not significant at 99:1. Bordeaux sprayed fruits were again significantly higher in soluble solids content than fruit from the lime-sulfur, proprietary coppers, organic and check plots in 1942, although no other differences were significant in all three states.

A lower soluble solids content of the fruit in 1941 from plots sprayed with organic materials without an arsenical suggested the possibility that the slightly higher soluble solids content of fruit from other plots which received an arsenical might be attributable to the use of lead arsenate in the spray combinations. The effect of arsenicals in hastening maturity of oranges is well established, although the effect is more one of altering the ratio between solids and acid content than an absolute increase in sugars (8). One series of plots (number 10) was sprayed in 1942 with Tennessee 26 and lime, but without an arsenical, to test this possibility. Analysis of fruit from the 1942 plots did not confirm the earlier hypothesis in this respect, however, as the soluble solids content did not differ significantly from that of plot 9 , the treatment of which differed only in the inclusion of lead arsenate in the spray combination. The soluble solids content of the fruit from plot 8 in 1942 (Compound 341) was low at all three stations, closely approximating and not significantly differing from the check. The impression gained from examination of the plots was that maturity of the fruit had been delayed on these trees, although it may have been that the rate of ripening of the other plots had been slightly accelerated by their treatments.

A series of plots in 1942 (numbers 11, 12, and 13) were sprayed uniformly with Tennessee 26 for the first three sprays, and then sprayed respectively with a pre-harvest application of Japanese Beetle Spray, Mike sulfur and Tennessee 26 Fungicide. The objective here was twofold: to secure better protection against brown rot during harvest, and to provide additional protection against leaf spot infection which might otherwise occur during the long period from the first cover to the post-harvest spray. The period between these two sprays may be from four to six weeks, during which time fungicidal protection may be reduced to a point where leaf spot infection begins to build up rapidly and cannot be satisfactorily held in check by a post-harvest spray.

Brown rot did not develop sufficiently in 1942 to provide a basis for fruit courits; so no data on the effectiveness of pre-harvest sprays on fruit rotting were obtained. The plots receiving either Japanese Beetle Spray or Tennessee 26 at the pre-harvest period retained their foliage slightly better than similar plots receiving either Mike sulfur or no spray at this time. 
Spray Injuries.-No separate record of defoliation due to spray injury was kept and therefore no definite appraisal can be made of the materials in this respect. A decision to mark the leaf stations before the first cover spray in future seasons was made in 1940 because of some evidences of injury and consequent leaf loss immediately following this spray, and before the station markers had been attached.

The leaves from all copper sprayed plots showed a typical injury to a certain extent every year, and this was especially noticeable in 1942. The first symptoms appear as small, superficial brown flecks on the lower leaf surface. The injury appears first along the midrib and may eventually' cover the greater part of the lower leaf surface. The injury was never more than superificial, although there were obvious gradations in severity. Affected leaves tended to curl upward and reveal the injured lower surface, giving the copper sprayed trees a bronzed-green appearance instead of the normal green foliage of those plots sprayed with lime-sulfur or the organic fungicides. The injury did not develop to the extent described until midsummer, at which time foliage loss on the checks and lime-sulfur plots had progressed to an advanced stage. There was a considerable amount of red mite injury in 1942 in the Pennsylvania and West Virginia plots, and although somewhat similar in appearance, the two injuries are readily distinguished upon close inspection.

The development of a characteristic type of stem-end or "copper ring" injury as reported by Miller ( 7 ) was observed at harvest time on those plots receiving copper fungicides. The injury appeared as a black line on the fruit at the base of the stem and more or less completely encircling it, yet separated from it by a narrow ring of normal tissue. The ring is rather inconspicuous on the fresh fruit but becomes apparent when the fruit is processed, and is objectionable in the pack. Observations on this type of injury were made in Pennsylvania and West Virginia, where it was found more or less uniformly on all plots sprayed with any copper fungicide. The incidence was somewhat greater on the proprietary copper fungicide plots than on those receiving Bordeaux mixture. The observations made in 1942 cannot be considered extensive enough to justify final conclusions, however. The development, or perhaps discovery, of this type of injury is of sufficient importance to require a more broadly based appraisal of copper materials before unconditional reocmmendation of their use can be made. Further information is needed on the conditions surrounding the development of this injury, such as the relation of age of fruit to susceptibility, the effect of the commonly used spray amendments and the influence of weather conditions.

The physiological effects of Bordeaux mixture on plants sprayed with it have been considered as a type of spray injury by some investigators. This is doubtless true in a broad sense, yet it seemed more appropriate to discuss 
such unique manifestations on the basis of the reflected effects rather than together with the more usual types of spray injuries.

\section{DISCUSSION}

A complete appraisal of a spray program for sour cherries in the Cumberland-Shenandoah region must include consideration of many factors aside from leaf spot control. These investigations have served to emphasize the necessity of giving appropriate weight also to spray injury, effects on fruit and seasonal variations as factors in the formation of a complete schedule. Liquid lime-sulfur has failed repeatedly to prevent late season leaf spot infection with subsequent defoliation, yet it gave good control early in the season when the foliage was developing rapidly, the fruit quite tender and the amount of leaf spot inoculum present comparatively small. Spray injury with lime-sulfur at this time has seemingly been of little consequence. The situation, however, changes more or less rapidly as the fruit approaches maturity. The fruit then becomes susceptible to sulfur sun scald, a predisposition further aggravated by higher temperatures. Sulfur-sprayed fruit also tends to scald in the field boxes when removal to the processing plant is delayed. The increased danger of foliage spray injury after harvest, and the failure to cope with the leaf spot situation makes the late season use of lime-sulfur even more hazardous.

These investigations have demonstrated that Bordeaux mixture possesses a high order of fungicidal effectiveness against cherry leaf spot, both early and late in the season. Foliage spray injury has not been consequential except perhaps in 1940. The tendency of the material to produce fruit injuries, particularly copper ring injury, requires further investigation. Bordeaux mixture has repeatedly caused a reduction in fruit size, confirming earlier observations of Fisher (5) and Dutton and Wells (3), and has increased the sugar content of the fruit, an observation first noted by Rasmussen $(\mathbf{1 0})$.

The proprietary copper fungicides have proved satisfactory as a rule in their ability to cope with leaf spot at all seasons, although variations as recorded earlier should be noted. These materials have produced little serious foliage injury, although the production of copper ring injury on the fruit is of sufficient gravity to render their unreserved recommendation inadvisable.

The organic fungicides differ widely as to composition and performance, although they are grouped under one typifying designation. The poorest organic material used ranked as the lowest of all treatments in leaf spot control, whereas the best one ranked alongside Bordeaux mixture. There were gradations between the two extremes. None of the organic materials caused what is commonly considered spray injury, although there was some 
evidence of retardation of maturity as measured by color development and soluble solids content. This cannot be considered as established, however, for the more advanced development of the fruit on the other plots may have been a reflection of a possible stimulation from lime, lead arsenate, or other materials. The fact that the condition of the fruit on the organic plots, generally, closely paralleled that of the unsprayed check suggests this latter interpretation.

The organic materials offer promise of future development and deserve consideration in this respect. No recommendation for their substitution for sulfur or copper materials on cherries appears justified at present.

The observations as recorded during the course of these experiments indicate the necessity of a split schedule for best results. One such schedule tested consisted of two lime-sulfur and two Bordeaux sprays, the first Bordeaux application being made at the first cover spray and the second as a post-harvest spray. A similar schedule with Bordeaux mixture shifted to the position of a pre-harvest application could be considered. Dutton and Wells (4) reported severe foliage injury following the use of a split lime-sulfur Bordeaux schedule and considered the practice unsafe; they however were apparently using a much stronger Bordeaux than was used in these experiments, and as used in this region. No injury attributable to the use of a split schedule has been observed in these investigations.

The limitation of pre-harvest applications of Bordeaux mixture to one has been suggested, both to minimize possible fruit injury, and to some extent avoid the dwarfing effect of the spray.

The use of Bordeaux mixture at the pre-harvest probably would not be objectionable where the fruit is to be processed in a commercial plant, as the residue is readily removed in the cold water storage process commonly employed. The visible residue would however be objectionable where the fruit is to be sold as fresh fruit. Lime-sulfur residue is not easily removed by washing or soaking.

Further investigations are indicated as necessary to clarify both the dwarfing effect and the cooper ring injury situation as related to the copper fungicides.

\section{SUMMARY}

Leaf spot is the most destructive disease of the sour cherry in the Cumberland-Shenandoah region. A fungicidal spray program of liquid lime-sulfur on cherries has been the standard practice for many years, although the limitations of lime-sulfur as a late season fungicide, plus a tendency to cause spray injury has caused a mounting dissatisfaction with the material among growers. The situation as it existed, when these studies were begun, applied to the entire region extending into several states. Workers in the states of Pennsylvania, Virginia, and West Virginia therefore planned and entered into 
a cooperative attack upon the problem in an effort to clarify the situation. A uniform approach was agreed upon at the outset and maintained throughout the course of the investigations with annual revisions made in accordance with each season's experience. The findings follow in brief outline.

A four-spray lime-sulfur program gave inadequate control, plus late season injury. Early lime-sulfur applications proved adequate to control infection at this time, although the importance of the petal fall and perhaps the shuck spray is problematic.

A four-spray Bordeaux schedule gave satisfactory control of leaf spot, but dwarfed the fruit. The sugar content of the fruit was increased, both relatively and in total amount.

Several of the proprietary copper compounds gave satisfactory disease control in a four-spray schedule but caused an objectionable type of fruit injury (7) observed in Pennsylvania in 1941 and in Pennsylvania and West Virginia in 1942.

The organic fungicides proved unsatisfactory as fungicides with but one exception. They caused no injury to fruit or foliage, although they may have caused some retardation of fruit development.

Split schedules appear to offer the most promise of a satisfactory solution at this time. Early-season applications of lime-sulfur are suggested as being adequate for leaf-spot control and relatively non-injurious to the fruit. Bordeaux mixture is suggested for the later applications as it possesses fungicidal potency adequate to control severe leaf-spot outbreaks, and is unlikely to affect the fruit seriously in applications made near harvest time.

\section{APPENDIX}

All tabular data upon which the statistical computations were made, and upon which previously expressed statements have been based, are given in tabular form in the pages following. Methods described by Snedecor (12, 13) and Hayes and Immer (6) were followed in computing the error values in these tables. Homogeneity $(6,12)$ of variances was determined for all the data in tables 4, 6, and 7. In tables 4 and 6 data from each state were tested for homogeneity of variances first. Data passing this test were then combined to determine homogeneity of the error sums of squares of the three states. No least significant difference or standard error values are given where non-homogeneity of variances was found. Least significant differences are also omitted where the $\mathrm{F}$ test indicated the treatment mean square to be non-significant. The treatment-by-state interaction was significant in the data on average leaf retention in tables $2,4,6$, and 7 , which can be interpreted as a differential response of the treatments in the different states. This indicates that some caution must be exercised in comparisons in the combined data. 
All statements in the text which are presented as significant are based on a single degree of freedom test according to the method of Snedecor (12). This formula can be applied to the averages in these tables by elimination of $k$ in the formula and using the square of the standard error of the mean treatment value for the $\mathrm{F}$ test. The standard error values apply to any mean in the column beneath which they occur.

The values for all plots, including unsprayed checks, were included in calculation of the error value in table 7. Calculation of error value for leaf retention data in table 2 did not include the check plot; in table 4, the checks and lime-sulfur plots; in table 6, the check, lime-sulfur, and Spergon plots. These were omitted since their values were so low that their variation was not of the same order as of the other plots.

Leaf spot in 1942 reached epiphytotic proportions earliest in Pennsylvania, next in West Virginia, and latest in Virginia. Late August counts in Pennsylvania were combined with mid-September counts in West Virginia and early October counts in Virginia in order to compare treatments at more nearly the same level of defoliation. A combination of all the October counts proved to have non-homogeneous variances. October counts were used for the 1940 and 1941 data.

Spray schedules for each year are given in detail for purposes of clarity and ease in following the treatment of each plot. 
Table 1.-1940 Spray Schedules, Materials and Rates of Usage 1

\begin{tabular}{|c|c|}
\hline Plot & Petal-Fall \\
\hline 0 & No spray \\
\hline 1 & Bordeaux, 2-4-100.2 \\
\hline 2 & Lime-sulfur, 2 gal. 3 \\
\hline 3 & Lime-sulfur, 2 gal. \\
\hline 4 & Cupro K, 3 . \\
\hline 5 & $\begin{array}{l}\text { Basicop, } 3 \text {; lime, } 8 \text {; zinc } \\
\text { sulfate monohy- } \\
\text { drate, } 1 / 2 \text {. }\end{array}$ \\
\hline 6 & $\begin{array}{l}\text { Phenothiazine, 4; lime, } \\
\text { 4. No lead. }\end{array}$ \\
\hline 7 & $\begin{array}{l}\text { Tank mix copper phos- } \\
\text { phate (copper sul- } \\
\text { fate, 2; tri-sodium } \\
\text { phosphate, 2; lime, } \\
3 . \text { ) }\end{array}$ \\
\hline 8 & $\mathrm{Z}=\mathrm{O}, 3$ \\
\hline 9 & Copper Hydro, 3. \\
\hline 10 & Copper-A Compound, \\
\hline 11 & Tennessee 26,3 . \\
\hline 12 & $\begin{array}{l}\text { Tennessee } 26,3 \text {; Or- } \\
\text { thex, } 1 \text { pint. }\end{array}$ \\
\hline 13 & $\begin{array}{l}\text { Tennessee } 26,3 \text {; } \mathrm{Nu}- \\
\text { film, } 1 \text { pint. }\end{array}$ \\
\hline
\end{tabular}

Shuck
No spray
Bordeaux, 2-4-100.
Lime-sulfur, 2 gal.
Lime-sulfur, 2 gal.
Cupro K, 3.
Basicop, 3; lime, 8; zinc
sulf a te m on o hy-
drate, 1/2:
Phenothiazine, 4 ; lime,
4. No lead.
Tank mix copper phos-
phate, 2-2-3.
T-O, 3.
Copper Hydro, 3.
Copper-A Compound,
T1/2.
Tennessee 26, 3.
thex; 1 pint.
Tennessee 26, 3; Nu-
film, 1 pint.

\begin{tabular}{|l|} 
First Cover \\
\hline \\
No spray \\
Bordeaux, 2-4-100. \\
Lime-sulfur, 2 gal. \\
Lime-sulfur, 2 gal. \\
Cupro K, 3. \\
Basicop, 3; lime, 8; zinc \\
sulf t te m on o hy- \\
drate, 1/2. \\
Phenothiazine, 4; lime, \\
4. No lead. \\
Tank mix copper phos- \\
phate, 2-2-3. \\
\\
Z-O, 3. Hydro, 3. \\
Copper Hyer-A Compound, \\
Copper 112. \\
Tennessee 26, 3. \\
Tennessee 26, 3; Or- \\
thex, 1 pint. \\
Tennessee 26, 3; Nu- \\
film, 1 pint. \\
\end{tabular}

Post-Harvest
No spray
Bordeaux, 2-4-100.
Limc-sulfur, 2. No lime.
Bordeaux, 2-4-100.
Cupro K, 3.
Basicop, 3; lime, 8; zinc
sul a t e m o n o h y-
drate, 1/2.
Yhenothiazine, 4; lime
4.
Tank mix copper phos-
phate, 2-2-3.

Z-O, 3. Hydro, 3.
Copper Hy
Copper-A Compound,
$11 / 2$.
Tennessee 26, 3.
Tennessee 26, 3; Or-
thex, 1 pint.
Tennessee 26, 3; Nu-
film, 1 pint.

1 All formulae are expressed in pounds per 100 gallons unless noted otherwise.

${ }^{3}$ Lead arsenate 2 lb.-100 was used in the first three applications on all sprayed plots except No. 6 .

${ }^{3}$ Lime 3 lb.-100 was used on all sprayed plots in all applications except where noted otherwise.

\section{Table 2.- Summary of Data for 1940. See Table 1 for Complete Schedule of Treatments}

\begin{tabular}{|c|c|c|c|c|c|c|c|c|}
\hline \multirow[b]{2}{*}{ Plot number } & \multicolumn{4}{|c|}{$\begin{array}{l}\text { Mean percentage of leaves } \\
\text { remaining early in October }\end{array}$} & \multicolumn{4}{|c|}{ Mean number fruits per pound } \\
\hline & $\mathrm{Pa}$. & Va. & W. Va. & Avg. & $\mathrm{Pa}$. & Va. & W. Va. & Avg. \\
\hline $\begin{array}{c}0 \\
1 \\
1 \\
3 \\
4 \\
5 \\
6 \\
10 \\
12 \\
13\end{array}$ & $\begin{array}{l}1.6 \\
68.9 \\
27.5 \\
64.9 \\
65.3 \\
55.1 \\
17.4 \\
61.9 \\
48.5 \\
68.2 \\
71.7 \\
67.0 \\
66.3 \\
66.9\end{array}$ & $\begin{array}{l}2.8 \\
51.1 \\
21.3 \\
69.0 \\
67.7 \\
52.6 \\
10.8 \\
61.4 \\
45.0 \\
64.6 \\
74.7 \\
67.1 \\
60.7 \\
71.9\end{array}$ & $\begin{array}{r}9.6 \\
56.8 \\
15.3 \\
65.7 \\
82.3 \\
88.9 \\
60.8 \\
79.0 \\
87.0 \\
83.2 \\
82.2 \\
83.3 \\
73.4 \\
85.2\end{array}$ & $\begin{array}{l}4.7 \\
58.9 \\
21.4 \\
66.5 \\
71.8 \\
65.5 \\
29.7 \\
67.4 \\
60.3 \\
72.0 \\
76.2 \\
72.5 \\
66.8 \\
74.7\end{array}$ & $\begin{array}{r}94.5 \\
116.2 \\
101.5 \\
100.2 \\
106.2 \\
103.8 \\
105.2 \\
112.0 \\
96.3 \\
102.2 \\
105.5 \\
106.3 \\
100.2 \\
104.0\end{array}$ & $\begin{array}{l}113.0 \\
127.2 \\
121.0 \\
121.2 \\
116.3 \\
123.3 \\
129.8 \\
129.8 \\
123.7 \\
114.0 \\
127.2 \\
126.3 \\
129.0 \\
121.8\end{array}$ & $\begin{array}{l}115.3 \\
129.5 \\
121.0 \\
119.3 \\
116.5 \\
117.0 \\
124.7 \\
124.0 \\
116.3 \\
120.3 \\
125.5 \\
120.8 \\
115.3 \\
114.2\end{array}$ & $\begin{array}{l}107.6 \\
124.3 \\
114.5 \\
113.6 \\
113.0 \\
114.7 \\
119.9 \\
121.9 \\
112.1 \\
112.2 \\
119.4 \\
117.8 \\
114.8 \\
113.3\end{array}$ \\
\hline $\begin{array}{l}\text { Least significant differ- } \\
\quad \text { ence }(99: 1) \\
\text { Standard error of a mean }\end{array}$ & $\begin{array}{r}17.5 \\
4.7\end{array}$ & $\begin{array}{r}22.2 \\
5.9\end{array}$ & $\begin{array}{r}17.0 \\
4.5\end{array}$ & $\begin{array}{r}10.8 \\
2.9\end{array}$ & $\begin{array}{r}13.4 \\
2.1\end{array}$ & 4.4 & $\begin{array}{r}10.9 \\
2.9\end{array}$ & $\begin{array}{l}7.8 \\
2.1\end{array}$ \\
\hline
\end{tabular}


Table 3.-1941 Spray Schedules, Materials and Rates of Usage 1

\begin{tabular}{|c|c|c|c|c|}
\hline Plot & Petal-Fall & Shuck & First Cover & Post-Harvest \\
\hline 0 & No spra & $y$ & $\mathrm{~N}$ & No s \\
\hline 1 & Lim & lfur & $1 \mathrm{r}, 2$ & alfur, \\
\hline$\frac{1}{2}$ & ulfur, 2 & lfur, & $\mathrm{r}, 2$ & Borde \\
\hline 3 & Bordeaux 2-8-100 & $x 2-8-100$ & Bordeaux 2-8-100 & Bordeaux 2-8- \\
\hline 4 & $-K, 3$ & $\mathrm{Cu}$ & Cupro-K, 3 & Cupro-K, 3 \\
\hline 5 & $\begin{array}{l}\text { Cupro-K, 3, plus } 1 \text { pint } \\
\text { S.E.C. Oil. }\end{array}$ & $\begin{array}{l}\text { Cupro-K, 3, plus } 1 \text { pint } \\
\text { S.E.C. Oil. }\end{array}$ & $\begin{array}{l}\text { Cupro-K, 3, plús } 1 \text { pint } \\
\text { S.E.C. Oil. }\end{array}$ & $\begin{array}{l}\text { Cupro-K, 3, plus } 1 \text { pint } \\
\text { S.E.C. Oil. }\end{array}$ \\
\hline 6 & Tennessee 26,3 . & Tennessee 26, 3 . & Tennessee 26,3 & Tennessee 26,3 \\
\hline 7 & Tennessee $34,21 / 4$ & Tennessee $34,21 / 4$ & e $34,21 / 4$ & ssee $34,21 / 4$ \\
\hline 8 & r Hydro, 3 & Hydro, 3. & Hydro, 3 & Copper Hydro, 3 \\
\hline 9 & Copper-A Compound, & Copper-A Compound, & Copper-A Compound, & Copper-A Compound, \\
\hline 10 & Apple Coposil, $31 / 2$ & Apple Coposil, $31 / 2$ & Apple Coposil, $31 / 2$ & Apple Coposil, $31 / 2$ \\
\hline 11 & Bordow, 6 & Bordow, 6 & Bordow, 6, no lime & Bordow, 6 \\
\hline 10 & $\begin{array}{l}\text { Japanese Beetle Spray, } \\
1 \mathrm{lb} \text {. }\end{array}$ & $\begin{array}{l}\text { Japanese Beetle Spray, } \\
1 \mathrm{lb} \text {. }\end{array}$ & $\begin{array}{l}\text { Japanese Beetle Spray, } \\
1 \mathrm{lb} \text {. }\end{array}$ & $\begin{array}{l}\text { Japanese Beetle Spray, } \\
\text { 1 lb. }\end{array}$ \\
\hline 13 & Fermate, 1. & Fermate, 1. & Fermate, 1. & Fermate, 1. \\
\hline
\end{tabular}

1 All formulae are expressed in pounds per 100 gallons unless noted otherwise.

2 Lead arsenate 2 lb. -100 was used in the second and third applications on all sprayed plots except Nos. 13 and 14

3 Lime 3 lb.-100 was used on all sprayed plots in all applications except plots 12 and 13.

- Black leaf 155 conc. 3 lb.-100 used as the insecticide in plots 12 and 13 .

Table 4.-Summary of Data for 1941. See Table 3 for.Complete Schedule of Treatments

\begin{tabular}{|c|c|c|c|c|c|c|c|c|c|c|c|c|c|c|}
\hline \multirow[b]{2}{*}{ Plot } & \multicolumn{4}{|c|}{$\begin{array}{l}\text { Mean percentage of } \\
\text { leaves remaining } \\
\text { early in October }\end{array}$} & \multirow{2}{*}{$\begin{array}{c}\text { Per- } \\
\text { cent- } \\
\text { age of } \\
\text { leaves } \\
\text { dis- } \\
\text { ease- } \\
\text { free } \\
\text { early } \\
\text { in Oc- } \\
\text { tober } \\
\text { Avg. }\end{array}$} & \multicolumn{4}{|c|}{$\begin{array}{l}\text { Mean number of fruits } \\
\text { per pound }\end{array}$} & \multicolumn{4}{|c|}{$\begin{array}{l}\text { Mean percentage of } \\
\text { soluble solids of fruit }\end{array}$} & \multirow{2}{*}{$\begin{array}{c}\text { Grams } \\
\text { soluble } \\
\text { solids } \\
\text { per } 100 \\
\text { fruit } \\
\text { Avg. }\end{array}$} \\
\hline & $\mathrm{Pa}$. & Va. & W.Va. & Avg. & & $\mathrm{Pa}$. & Va. & W. Va. & Avg. & $\mathrm{Pa}$. & Va. & W.Va. & Avg. & \\
\hline $\begin{array}{r}0 \\
1 \\
2 \\
3 \\
4 \\
5\end{array}$ & $\begin{array}{l}14.5 \\
29.6 \\
34.4 \\
58.5 \\
45.9 \\
44.1 \\
53.7 \\
52.5 \\
55.2 \\
52.1 \\
54.7 \\
66.6 \\
64.9 \\
44.1\end{array}$ & $\begin{array}{r}2.4 \\
42.1 \\
59.5 \\
80.8 \\
75.8 \\
75.4 \\
72.7 \\
81.4 \\
80.2 \\
84.8 \\
83.2 \\
85.7 \\
70.8 \\
86.1\end{array}$ & $\begin{array}{r}0.6 \\
14.1 \\
66.4 \\
76.8 \\
76.6 \\
71.4 \\
87.4 \\
91.3 \\
90.5 \\
91.4 \\
90.9 \\
87.8 \\
72.4 \\
27.4\end{array}$ & $\begin{array}{r}5.8 \\
28.6 \\
53.4 \\
72.0 \\
66.1 \\
63.6 \\
71.3 \\
75.1 \\
75.3 \\
76.1 \\
76.2 \\
80.0 \\
69.4 \\
52.5\end{array}$ & $\begin{array}{r}1.7 \\
9.3 \\
45.6 \\
92.0 \\
58.7 \\
58.1 \\
73.4 \\
89.3 \\
84.1 \\
78.9 \\
74.9 \\
84.5 \\
47.5 \\
38.8\end{array}$ & $\begin{array}{r}99.5 \\
97.3 \\
97.3 \\
102.5 \\
99.7 \\
97.3 \\
97.3 \\
93.3 \\
96.2 \\
91.5 \\
91.2 \\
96.3 \\
90.0 \\
93.7\end{array}$ & $\begin{array}{l}106.8 \\
109.0 \\
110.3 \\
122.0 \\
117.0 \\
105.0 \\
109.3 \\
112.6 \\
111.1 \\
109.8 \\
112.1 \\
119.1 \\
104.8 \\
110.5\end{array}$ & $\begin{array}{l}115.7 \\
122.0 \\
124.5 \\
129.7 \\
119.8 \\
114.5 \\
117.2 \\
118.0 \\
124.3 \\
115.2 \\
127.5 \\
123.5 \\
124.8 \\
129.8\end{array}$ & $\begin{array}{l}107.3 \\
109.4 \\
110.7 \\
118.1 \\
112.2 \\
105.6 \\
107.9 \\
108.0 \\
110.5 \\
105.5 \\
110.3 \\
113.0 \\
106.6 \\
111.3\end{array}$ & $\begin{array}{l}15.1 \\
14.8 \\
14.5 \\
16.6 \\
14.9 \\
15.1 \\
14.5 \\
14.0 \\
14.5 \\
14.2 \\
14.7 \\
14.9 \\
13.9 \\
14.5\end{array}$ & $\begin{array}{l}13.4 \\
14.6 \\
15.4 \\
17.4 \\
15.3 \\
14.9 \\
15.1 \\
15.3 \\
15.0 \\
15.3 \\
15.6 \\
15.7 \\
13.8 \\
14.0\end{array}$ & $\begin{array}{l}13.6 \\
14.6 \\
14.8 \\
16.5 \\
14.9 \\
14.3 \\
15.1 \\
15.0 \\
14.8 \\
15.1 \\
15.0 \\
15.1 \\
14.3 \\
14.7\end{array}$ & $\begin{array}{l}14.0 \\
14.7 \\
14.9 \\
16.8 \\
15.0 \\
14.8 \\
14.9 \\
14.8 \\
14.8 \\
14.9 \\
15.1 \\
15.2 \\
14.0 \\
14.4\end{array}$ & $\begin{array}{l}59.4 \\
60.7 \\
61.0 \\
64.6 \\
60.8 \\
63.4 \\
62.6 \\
62.0 \\
60.6 \\
63.9 \\
62.1 \\
61.1 \\
57.1 \\
56.4\end{array}$ \\
\hline $\begin{array}{l}\text { Least sig. dif. } \\
(99: 1) \\
\text { Standard er- } \\
\text { ror of a } \\
\text { mean }\end{array}$ & 13.7 & 15.3 & 18.5 & 2.5 & & 2.7 & 12.7 & 14.2 & 1.9 & 1.25 & 1.22 & .23 & .17 & \\
\hline
\end{tabular}




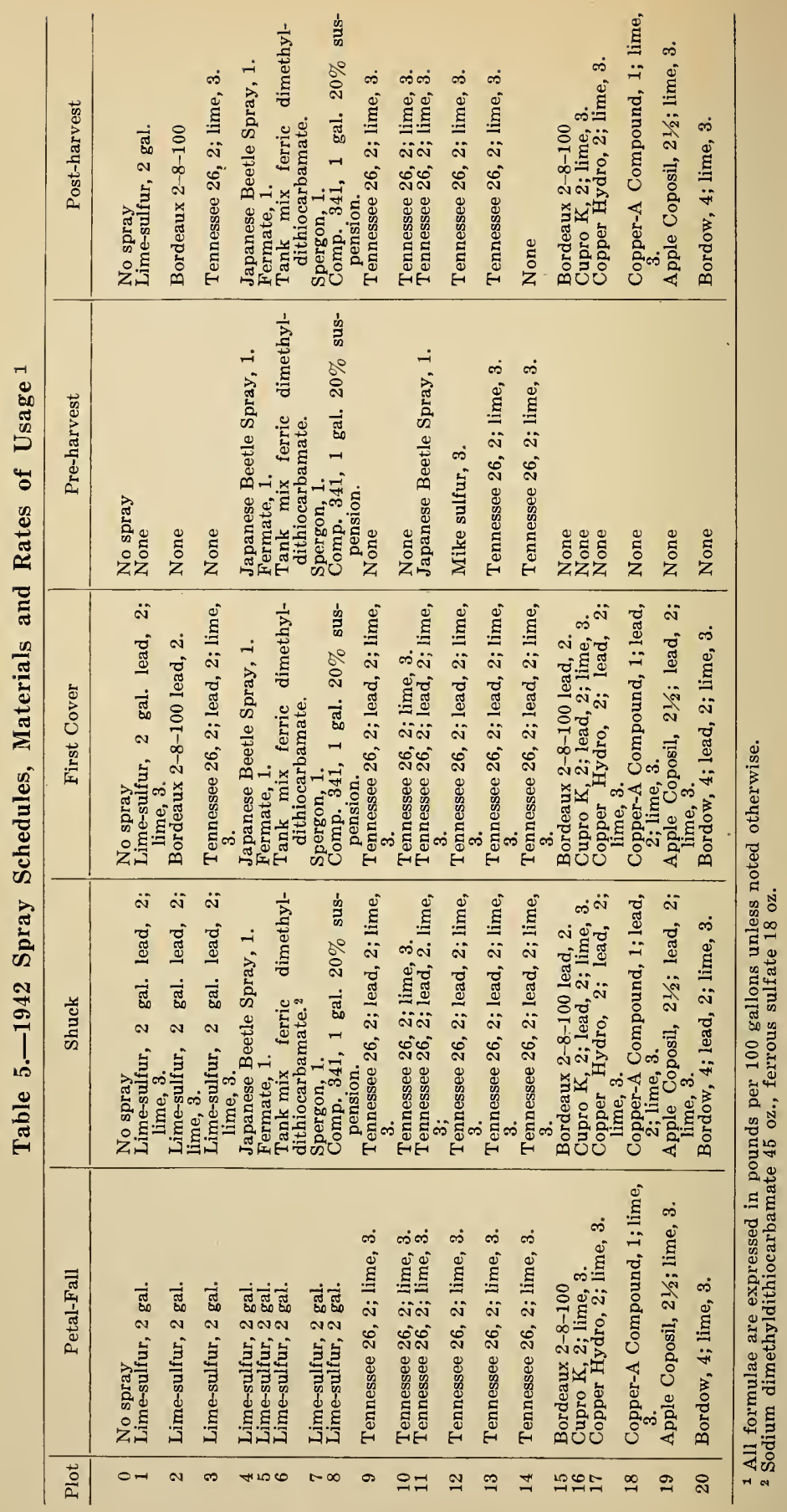




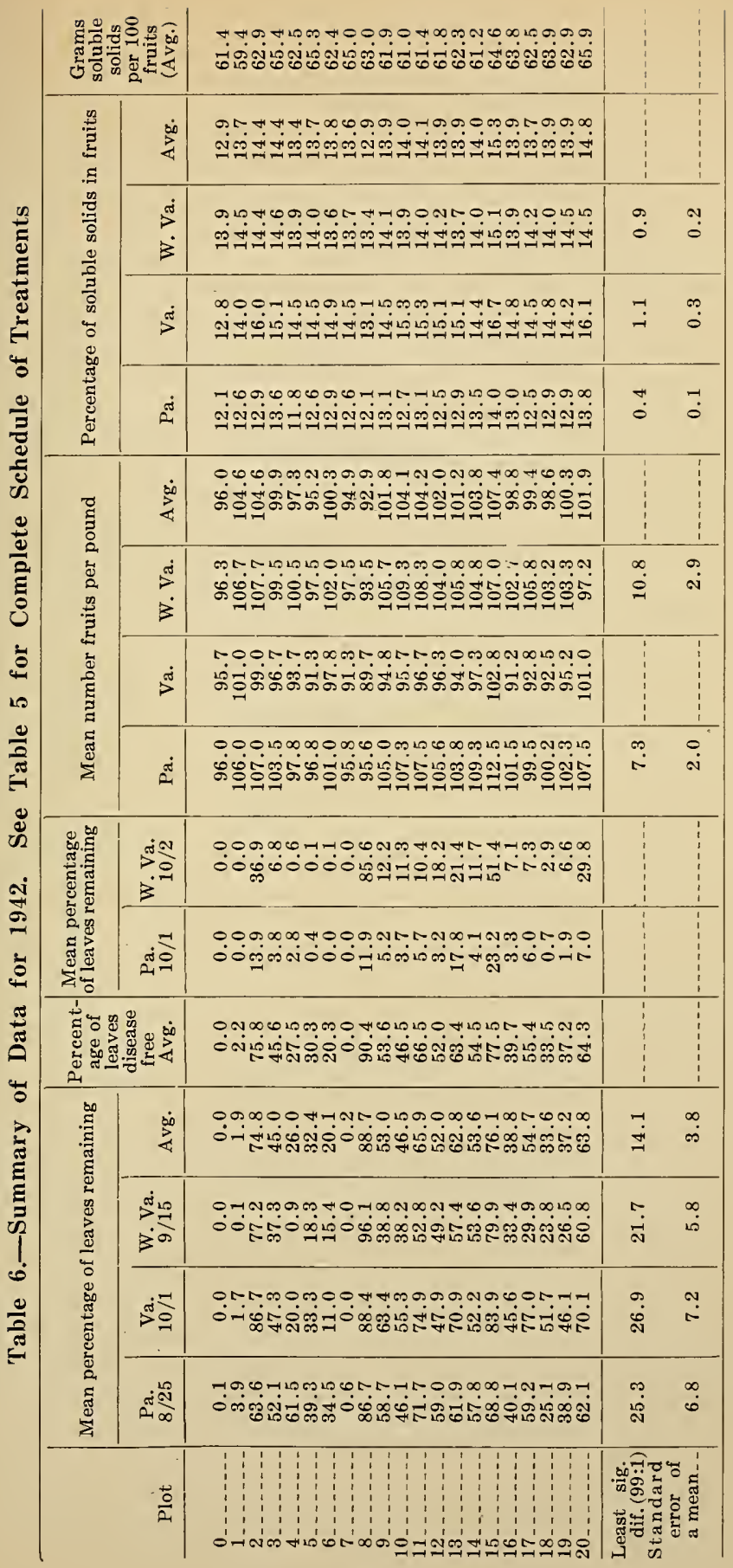


Table 7.-Summary of Leaf Retention Data from Materials Tested for More Than One Year

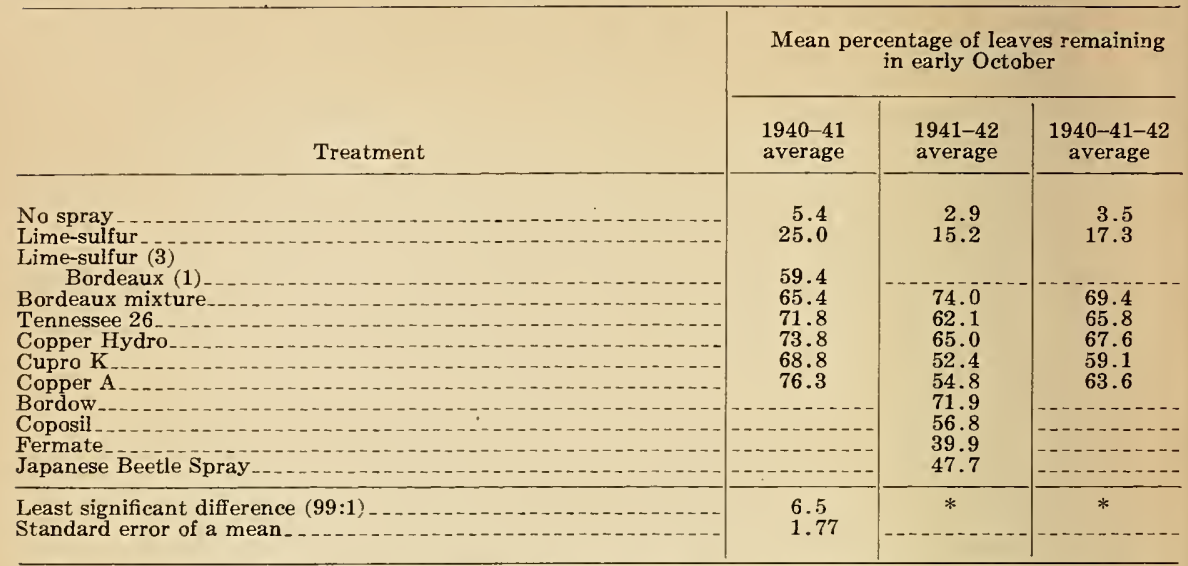

Pennsylvania and West Virginia 1942 data were based on counts made before October (see appen$\operatorname{dix})$.

The error sums of squares of the component experiments proved to be non-homogeneous (6). 


\section{LITERATURE CITED}

1. Allinger, H. W., Bisson, C. S., Roessler, E. B., and MacGillivray, John H. 1940. MEASUREMENT OF SOLIDS IN MELON JUICE.

Proc. Amer. Soc. Hort. Science 38: ร63-5666.

2. Association of Official Agricultural Chemists.

193\%. OFFICIAL AND TENTATIVE METHODS OF ANALYSIS.

Ed. 4, Assoc. Off. Agr. Chemists, Washington, D. C. (Ref. Table 6, Ch. XLII).

3. Dutton, W. C., and Wells, H. M.

1923. SOME PHYSIOLOGICAL EFFECTS OF BORDEAUX.

Proc. Amer. Soc. Hort. Science 21: 277-281.

4. -

192ว. CHERRY LEAF-SPOT.

Mich. Agr. Exp. Sta. Special Bul. No. 147: 13.

5. Fisher, D. F.

1921. EFFECT OF ALKALINE SPPRAYS ON THE SIZE OF SWEET CHERRIES.

(Abstract) Phytopathology 12: 104.

6. Hayes, H. K., and Immer, F. R.

1942. METHODS OF PLANT BREEDING. 432 p. illus.

McGraw-Hill Book Co., Inc., New York.

7. Miller, H. J.

1943. RELATION OF DOSAGE OF CERTAIN COPPER SPRAYS TO COPPER INJURY AND LEAF-SPOT CONTROL ON MONTMORENCY CHERRY.

(Abstract) Phytopathology 33: 9.

8. Miller, R. L., Bassett, Ione P., and Yothers, W. W.

1933. EFFECT OF LEAD ARSENATE INSECTICIDES ON ORANGE TREES IN FLORIDA.

U. S. Dept. of Agr. Tech. Bul. 350, 1-20.

9. Porter, D. R., Bisson, C. S., and Allinger, H. W.

1940. FACTORS AFFECTING THE TOTAL SOLUBLE SOLIDS, REDUCING SUGARS, AND SUCROSE IN WATERMELONS. Hilgardia 13, No. 2: 31-66.

10. Rasmussen, E. J.

1939. THE EFFECT OF SEVERAL SPRAY MATERIALS ON THE 
SIZE, COLOR AND PERGENT SOLIDS OF THE FRUIT OF THE MONTMORENCY CHERRY.

Proc. Amer. Soc. Hort. Science 37: 367-370.

11. Schneiderhan, F. J.

1932. INSTANT BORDEAUX.

W. Va. Agr. Exp. Sta. Circ. 60.

12. Snedecor, G. W.

1938. STATISTICAL METHODS.

Ed. 2, 388. Collegiate Press, Ames, Iowa.

13. - -

1940. STATISTICAL METHODS.

Ed. 3, 422. Collegiate Press, Ames, Iowa.

14. Thurston, H. W. Jr., Taylor, C. F., Groves, A. B., and Miller, H. J.

1942. INTERSTATE COOPERATIVE EXPERIMENTS ON FIELD SPRAYING OF SOUR CHERRIES.

Phytopathology 31, 11: 1047-1050. 



